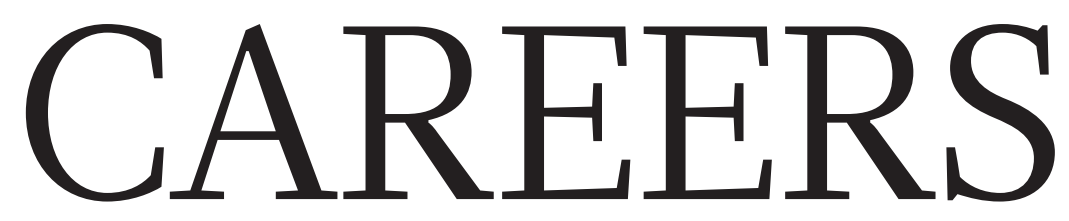

LET THEM LIVE A biologist advocates the importance of skin bacteria p.129
BLOG Personal stories and careers counsel go.nature.com/2k53ee5
NATUREJOBS For the latest career listings and advice www.naturejobs.com

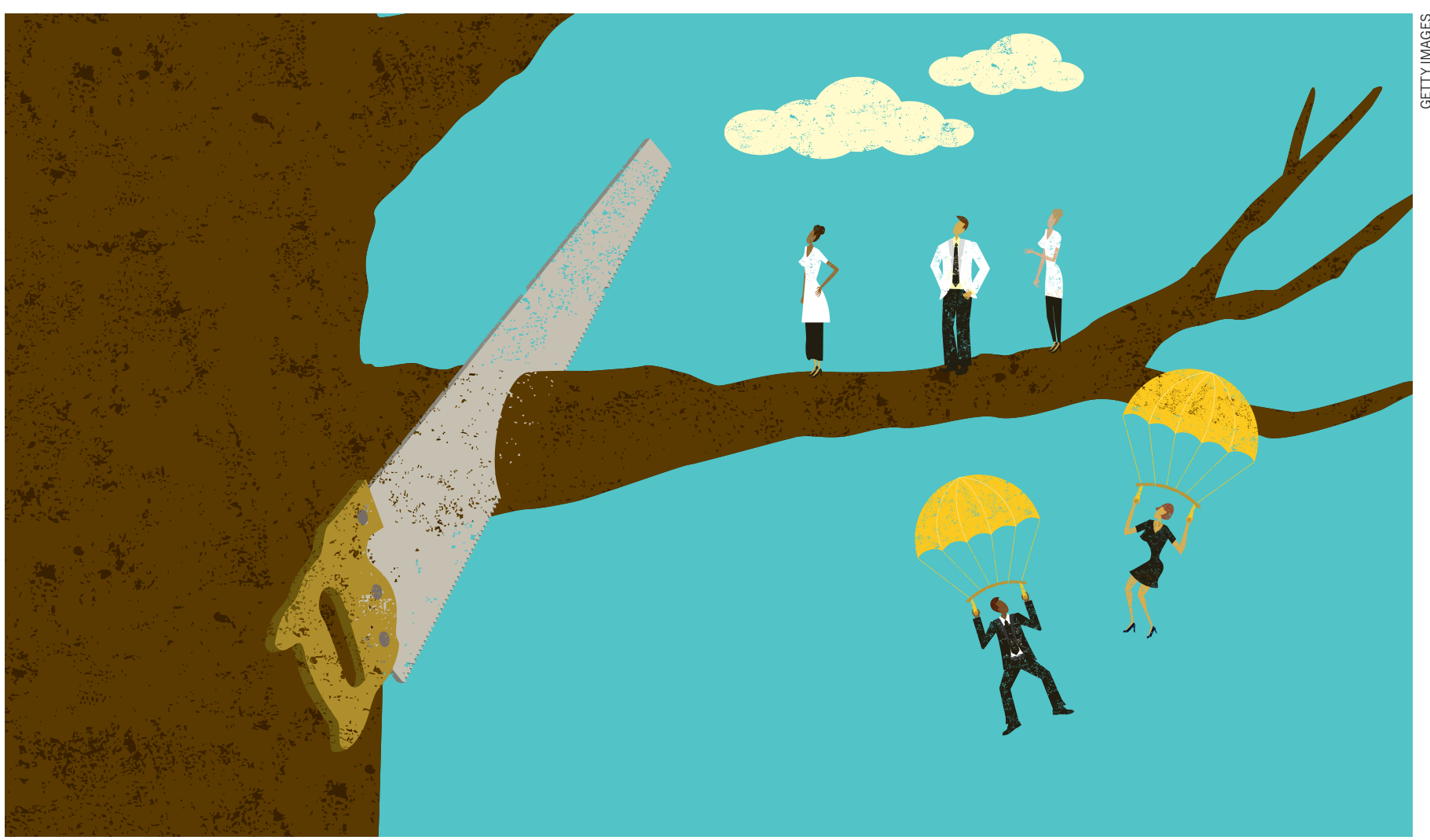

\title{
COLUMN
}

\section{Look before you leap}

\section{If your job is at risk, don't wait until the last minute before planning a safe landing, says Peter Fiske.}

A s scientists, we go through our day assuming that our job security is inextricably tied to the quality and quantity of the great science that we do. If our work assignment or employment status is potentially subject to changes, we also assume that we will learn about them well in advance and that we will have ample time to make a smooth transition to our next assignment.

Do not make these assumptions. Prepare yourself now for such a change and know how to navigate it - before it is too late. If it is of any comfort, I am beginning this journey myself. For eight years, I led a technology startup; now it is being acquired, and my position is history. Even for a 'career expert' such as myself, an unplanned change of employment is emotionally fraught and unsettling.

The secure research-science job is an illusion in any sector - not just in academia but also in government, non-profit organizations and industry. Today, many forces, such as changes in economic growth, government policy and priorities, or political referendums such as the Brexit vote, buffet the global research enterprise. All career sectors are subject to shocks and disruptions and have been forced to adapt to the new reality of job insecurity. Science has no special privileges: why should we expect job insecurity not to affect us too?
In the face of employment uncertainty, whether real or imaginary, you cannot afford to remain passive. Not only must you avoid assuming that your job will remain secure, but you must prepare now for the worst-case scenario - job loss. But do not become discouraged. People who are trained in science have many transferable and highly valued skills and traits. I am optimistic about my future, and so should you be about yours.

\section{FIRST STEPS}

Your first reaction to a potential, or impending, job disruption should be to ascertain when it's likely to happen, how long it might last, 
> and what resources - financial, legal, professional — are available to you. Get the most recent copy of your employment contract or agreement and any related documentation, such as invention or intellectual-property agreements, so that you understand what provisions will be triggered with a termination of employment. These could include a severance package — or a non-compete obligation, requiring you to avoid working for any organization that competes with your current employer, either for a specific period or indefinitely.

Your network plays a huge part in helping you to identify opportunities and make successful career transitions (see go.nature. com/2koaffc). But however extensive that network, you will probably have an inner circle of two to four contacts (professional or personal) to whom you are particularly close, and who are the most likely to be willing to help.

Contact these people immediately you learn that a change in your job is imminent. Tell them what's going on and discuss your concerns. These are trusted friends who will listen, help you to process the difficult emotions you are experiencing and, importantly, remind you of your skills and qualities. They will also be the first to help you ferret out new opportunities.

Job transitions usually take several months. So it's always best to start looking for a new job before you lose - or leave - your current one. Prospective employers generally perceive you as a stronger candidate if you are in work when you apply; and even if your job situation is precarious, you have more options.

Another reason for starting your job search in good time is that you may not be especially effective at conducting such a search if you have just learnt that your job is threatened. At this point, you are likely to experience a cascade of emotions including disbelief, resistance, anger, sorrow and fear. Don't worry: these feelings are natural.

\section{PONDER THE OPTIONS}

Once you've got the ball rolling, it's time to explore some hypothetical moves. Ruminate on and envision specific jobs or career paths that appeal to you. Be as specific as you can about the institutions, organizations and job roles that might interest you. Resist the instinct to immediately analyse the feasibility of any particular career move, or to dwell on the barriers that might make it difficult. Instead, focus on what the new job or organization might be like and on the positive aspects of your potential position. For example, could a move out of academia lead to a substantial increase in pay and benefits? Try to focus on the upsides of any new job and don't slide into negative thoughts about its shortcomings or what you might be leaving behind.

Considering these issues while staying positive is not easy. Two techniques help: scheduled periods of reflection and recording your feelings and ideas in a journal. Set aside an hour

\section{INTERVIEW TIPS \\ Seal the deal}

Whether you're going for an informational interview or a job interview, you need a strategy that maximizes your chances of making a good impression and moving to the next step. Here are some key tips.

\section{BEFORE THE INTERVIEW}

- Go in prepared Fully research the organization or company that you are interviewing with. Seek out any documents or statements on its website about its strategic plans or future directions. Understand where your opportunity might lie within the structure of the organization. - Use LinkedIn groups Linkedln has more than 1 million groups covering myriad technical subjects. Many larger organizations and companies also have Linkedln groups that have been started by current or former employees. Join the groups that connect to the organization or company you are applying to, and read through past discussions and comments. Consider posting a question yourself for these groups, such as: "I am scheduled for an interview next month — what advice do you have for me?"

\section{- Find out who you are meeting and} where they are in the organization Many employers will provide you with an agenda for the day of your visit, including the names and positions of the people you will be speaking with. If they don't, politely enquire if they can give you that information. Look up each individual on the organization's website or Linkedln page and familiarize yourself with their background and experience, and where they fit within the organization.

- Get advice from your network If you have landed the informational interview or job interview with the help of someone in your network, be sure to circle back to them and gather any advice they have about how to approach the interview process.

\section{DURING THE INTERVIEW}

- Cover key points In an informational interview, explain to everyone you meet why you are interested in their career field or organization. In a job interview, give three good reasons why the position interests you and why you are well qualified for it.

- Get business cards from each of the people you meet You will need to e-mail them later.

- Know what the next steps are, and when they're likely to happen Many people leave a job interview exhausted and excited, but uncertain when they'll hear back. Ask the people you meet how far through the hiring process they are, and when they expect to make a decision. If you haven't heard by that time, you can follow up with them.

\section{AFTER THE INTERVIEW}

- E-mail a brief thank-you to each of the people you met Express your interest in and enthusiasm for the position.

- Contact the members of your network Let them know how the interview went, and when you expect to hear a decision. Sometimes they can make polite enquiries on your behalf. P.F. or two each week, leave your workplace or home and sit somewhere comfortable but not overly familiar. Force yourself to write down all your feelings and ideas, as well as details of the potential jobs or career shifts you can think of. The notebook or digital document becomes your 'transition journal'. As you proceed in your job search, record your notes and thoughts in this journal. After a few weeks, you will begin to see patterns emerge in the things that interest you, and this will help you to know which options to pursue.

One colleague of mine, facing sudden uncertainty about the renewal of her contract, started brainstorming about possible research collaborations. She listed 12 organizations that she had interacted with, reviewed their websites and found a few that contained information on strategic plans or similar statements of research priority. Two of the organizations had direct connections with her current research. In her transition journal, she continued to brainstorm about potential collaborations, knowing that starting a research programme with another institution greatly increases the odds of eventually being hired by that institution. In the end, her current lab renewed her contract, but she launched the external collaboration anyway. As a result, she gained a new area of research, new collaborators and a clear sense of her own career resilience.

\section{GO PUBLIC}

At some point, whether you've already lost your job or not, you will need to discuss your search with your larger network. This can be the scariest point of the transition process because you are publicly acknowledging your vulnerability. But this is the best time to bring the issue to 
your larger network - after you've already considered specific jobs, fields, disciplines or sectors that you might want to explore. As soon as you alert those in your network that you're on a job hunt, you can begin to gather information from them. For example, they might be able to tell you which companies and other employers are hiring.

During this period, your network will provide you with job leads and introduce you to people in career fields or organizations that interest you. Arrange informational interviews to learn what it's like working for such companies (see 'Interview tips' and go.nature.com/2jodnzz). Going public about your job search requires delicacy if you are still employed. Be discreet and ask the people you speak with to do likewise. (Bear in mind, however, that it's impossible to keep everything under wraps in today's digital era.)

You should meet face-to-face with people in your network and those to whom they introduce you. It is best to schedule as many of these encounters as you can - including daily lunch dates, even if these are just with a friend. The conversations will be deeper and more candid than a phone or e-mail exchange would be, and you'll gain more support, and more information, from them. And try to not eat alone at your desk every day. Social isolation during this period of uncertainty will only amplify your anxiety.

\section{SEIZE EVERY CHANCE}

Eventually, having waded in uncertainty with nothing specific ahead, you will uncover a bona fide job opportunity. Even if the job is far from ideal, I urge you to apply for it and pursue it with conviction. Entering the application process half-heartedly, or with lingering feelings of anger or frustration over your loss, will put you at a disadvantage with your prospective employer because you will make a less favourable impression than other candidates. This application is a crucial first step and will set the tone for others to come. Although you may not receive an offer, the process itself will exercise thought muscles that may have lain dormant for years. You will be a stronger and more polished applicant when future job opportunities arise.

At some point, you might also find yourself in the enviable position of simultaneously considering several desirable job offers. You will be able to mull the pros and cons of each, and to negotiate the best deal with confidence before choosing. At this point, your transition will be complete: the crystalline structure of your past employment will have been transformed into something new. Congratulations!

Peter Fiske is the former chief executive of PAX Water Technologies in Richmond, California, and author of Put Your Science to Work (American Geophysical Union, 2001).

\section{TURNING POINT Microbe detective}

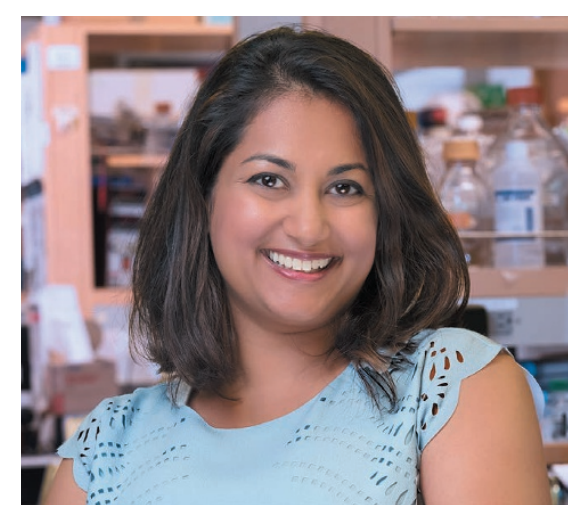

Shruti Naik's stand-up comedy career plans were derailed by glow-in-the-dark bacteria. After watching a TV programme about how bacteria sense each other, Naik decided to study molecular biology and is now a postdoc at the Rockefeller University in New York City. Her research on the skin microbiome contributed to the introduction last year of a US government ban on commercial soaps containing any of 19 different antibacterial chemicals. In the same year, she was named a L'Oréal USA 'For Women in Science' fellow, and she now has plans to start a podcast for female scientists to share their career stories.

\section{Why were you drawn to stand-up comedy?}

I moved from India to America when I was 12. It was a culture shock. I dealt with that through humour. It helped to make jokes about the differences in basic communication. It also helped that I went to a high school with a strong arts programme, and I had a theatre teacher who was a stand-up comedian and improvisational performer.

\section{When did you see the video about bacteria?} I was in high school and flipping through channels on TV when I saw Bonnie Bassler, a molecular biologist at Princeton University in New Jersey, talking about glowing bacteria. I just thought it was really cool. I didn't understand what a big deal it was that the microbes behave as multicellular organisms. I took a microbiology class in high school, and was completely hooked on bacteria.

\section{Did you dive into science at university?}

Yes. I studied cell and molecular biology at the University of Maryland in College Park. But it wasn't clear to me what basic research was all about, or how exciting and fun it could be. I joined the US Food and Drug Administration lab on campus, where we were essentially detectives. If there was a food-related disease outbreak in the country, it was our job to find the culprit. It was like 'CSI' for spinach.

\section{Did you go straight for a PhD?}

No. I took two years off between undergraduate and graduate school and worked for the Naval Medical Research Center in Silver Spring, Maryland, in a lab that studied immune responses to traumatic brain injury. There, I became interested in immunology. I earned my $\mathrm{PhD}$ while researching the dialogue between microbe and host. I give my mentor, Yasmine Belkaid, an immunologist at the US National Institute of Allergy and Infectious Diseases in Bethesda, Maryland, so much credit for her unabashed encouragement of my interest in the skin microbiome when others said I was crazy. At the time, most work in the microbiota field focused on the gut. Other bacterial niches - skin, oral cavity and lungs - received little attention.

\section{Why did you choose to research skin?}

I think naivety receives most of the credit. There was no rational reason other than I just thought skin was a really cool organ and we knew that bacteria live on skin. But I wanted to know why they were there.

\section{How did your work help lead to a ban on} 19 antibacterial chemicals in soap?

It's not like my work said something new that we didn't know about. But we were able to show that the skin has these bacteria, that they are important and that we shouldn't shower ourselves with these products that contribute to antibiotic overuse.

\section{Where are you taking your research now?}

I want to learn how tissues experience and respond to environmental stimuli, whether that's nutrition, temperature or inflammatory stress. I'm studying how inflammatory stress affects epidermal stem cells' long-term fitness.

What do you hope to achieve with your podcast? I want to humanize female scientists and connect younger and older generations. One of the podcasts will feature other L'Oréal-fellowship winners talking about their role models. I want to make these accomplished women more accessible, and to show that everyone has moments of doubt and experiences difficulties. The lesson I hope that women will take away is that self-doubt is normal - just go for it.

\section{INTERVIEW BY VIRGINIA GEWIN}

This interview has been edited for clarity and length. 